\title{
Clinical significance of BAALC overexpres- sion for predicting post-transplant relapses in acute myeloid leukemia
}

\author{
Alena I. Shakirova, Nikolay N. Mamaev, Ildar M. Barkhatov, Yana V. Gudozhnikova, Tatiana L. Gindina, Elena V. Babenko, \\ Boris V. Afanasyev \\ Raisa Gorbacheva Memorial Research Institute of Pediatric Oncology, Hematology and Transplantation, Pavlov First Saint \\ Petersburg State Medical University, St. Petersburg, Russia
}

Dr. Biol. Alena I. Shakirova, Laboratory of Molecular Hematology and Transplantation, Raisa Gorbacheva Memorial Research Institute of Pediatric Oncology, Hematology and Transplantation, Pavlov First Saint Petersburg State Medical University. Roentgen St 12, 197022, St. Petersburg, Russia
Phone: +7 (911) 7335148

E-mail: alyona.i.shakirova@gmail.com

Citation: Shakirova AI, Mamaev NN, Barkhatov IM et al. Clinical significance of BAALC overexpression for predicting post-transplant relapses in acute myeloid leukemia. Cell Ther Transplant 2019; 8(2): 45-57.

\section{Summary}

The aim of this study was to clarify close associations between population of bone marrow blast elements defining cytological relapse, and that of leukemic precursor cells by means of serial quantitative measurement of WT1 and BAALC molecular markers expressed by appropriate cell types. In clinical terms, we sought to evaluate a potential for evolving leukemia relapses following hematopoietic stem cell transplantation (HSCT). The post-transplant relapses (PTR), in view of their biological mechanisms, may be detected by overexpression of distinct differentiation-related genes.

\section{Patients and methods}

We have done parallel serial measurements of BAALC and WT1 gene expression in bone marrow cells of the patients with acute myeloid leukemia, using quantitative real-time PCR (qPCR) with gene-specific primers.

\section{Results}

An initial pilot study was carried out in twelve patients with elevated WT1 expression levels and normal blast counts $(<5 \%)$ in bone marrow at the time of allogeneic HSCT. It has shown that the relapse occurrence and shorter relapse-free survival (RFS) post-transplant were more common in the subgroup with higher $B A A L C$ gene expression level as compared to those without $B A A L C$ expression elevation ( $\mathrm{p}=0.002$, and $\mathrm{p}=0.019$, respectively).
Moreover, when analyzing the validating patient cohort, we have found that the simultaneous elevation of both BAALC and WT1 expression, known as unfavorable prognostic factor, was more frequently observed in the patients with AML M1, M2, and M0 FAB-variants. Preliminary results show an inferior overall survival (a mean of 228 days) in AML patients with combined overexpression of the both genes immediately before HSCT, like as in post-transplant period. In conclusion, it should be noted that our findings of simultaneous overexpressions of BAALC and WT1 genes in great cohort of adults and children patients with different FAB- variants of AML treated by means of allo-HSCT were revealed for the first time. Being associated with poor prognosis, this double test should be used actively for post-transplant monitoring of all patients with AML.

\section{Keywords}

Acute myeloblastic leukemia, hematopoietic stem cell transplantation, allogeneic, post-transplant relapses, $B A A L C, W T 1$, gene overexpression, parallel assays, relapse risk, prognostic value. 


\section{Introduction}

The Brain And Acute Leukemia Cytoplasmic (BAALC) gene becomes a new molecular star on the horizon of leukemia research. Its protein was initially discovered in the cytoplasm of central nervous system neuroderm cells [1]. Later on, a sufficient role of $B A A L C$ gene overexpression as a prognostic marker and pathogenetic factor of acute myeloid leukemia (AML) proved to be more obvious [2-4]. Initially, the BAALC overexpression was revealed in the patients with chromosome 8 trisomy, wherein $B A A L C$ gene maps. More recently, this abnormality has been demonstrated in $50-60 \%$ of AML patients with different morphological and cytogenetic variants [5-8]. Thus, BAALC gene overexpression proved to be rather specific for AML patients with $t(8 ; 21)$ translocation [5]. Meanwhile, the incidence of such phenomenon was also high in M0 and M1 AML FAB-variants [6]. On the contrary, it was observed extremely rare in AML M3 [7].

The BAALC gene expression has been recently shown to be closely associated with leukemic CD34+ but not CD34- precursor cell population which may initiate a relapse of acute leukemia that was shown in experiments with precursor cell enrichment [9-11]. Great contribution of early leukemic precursors, particularly CD34+/CD38- cells, to BAALC expression was demonstrated in other works [12], as documented by growing number of studies in the field [4, 13-18]. It is essential that the above-mentioned precursor cells with CD34+/CD38- phenotype may be responsible to regulate size of blast cell population, which, in turn, is able to express WT1 gene mRNA. Therefore, the latter gene is considered to be a basic molecular marker for AML relapses [19]. Since both these markers are functionally associated with changing levels of leukemic cells in AML patients treated by allogeneic hematopoietic stem cell transplantation (allo-HSCT), the parallel study of their expression seems to be quite important both in clinical and tumor biology aspects $[5,20]$.

One of such studies [5] included a cohort of 45 adult patients with core-binding-factor-positive AML, of which 28 cases had a standard $\mathrm{t}(8 ; 21)$ translocation, and 17 patients harbored the inv(16) aberration. This work revealed that the patients with elevated $B A A L C$ gene expression level at diagnosis had shorter overall survival (OS) and relapse-free survival (RFS) $(\mathrm{p}=0.031$, and $\mathrm{p}=0.011$, respectively) along with significantly increased cumulative incidence of relapse (CIR) post-transplant $(\mathrm{p}=0.002)$. In this setting, the decrease of $B A A L C$ gene expression level following induction chemotherapy had no impact on results of allo-HSCT or auto-HSCT in one-third of this group.

This study has shown for the first time that the elevated $B A A L C$ and WT1 gene expression levels over post-transplant period in the patients with core-binding-factor-positive AML may be associated with unfavorable clinical prognosis. It should be noticed here, that all the associations between BAALC and WT1 gene expression and basic clinical parameters were obtained in the cohorts with intermediate or favorable cytogenetic AML variants. At the same time, such associations are not confirmed in more heterogeneous groups of patients, including both favorable and dismal AML variants [21]. When explaining these differences in clinical and laboratory characteristics among two patient groups, we consider an important role of particular chromosomal aberrations to be responsible for the transformation of leukemic cell precursors from the sleeping condition to more active state.

The aim of this study was to clarify close associations between population of bone marrow blast elements defining cytological relapse, and that of leukemic precursor cells by means of serial quantitative measurement of WT1 and $B A A L C$ molecular markers expressed by appropriate cell types.

\section{Patients and methods}

Our study presents the data on WT1 and BAALC gene expression levels measured in parallel, during serial assays of bone marrow samples taken from sixty-one patients with initial diagnosis of AML. All the patients were treated with allo-HSCT at R. Gorbacheva Memorial Research Institute of Children Oncology, Hematology and Transplantation (St. Petersburg) from 2010 to 2016 years. The study group included 27 females and 34 males at the age of 3 to 66 years (median age 23.5 years old). Twelve patients were classified into the group with evident cytological remission $(<4 \%$ in the bone marrow) at the time of HSCT, however, showing WT1 overexpression in the marrow samples [22]. Among the remaining 49 patients with different AML FAB-variants, serial BAALC and WT1 expression changes have been evaluated individually, being combined with blast cell counts in the same bone marrow aspirates.

Total mRNA extraction from fresh bone marrow samples, its reverse transcription and quantitative estimation of the $B A A L C$ gene expression level were performed as previously described [23]. Basic control time points for bone marrow sampling were as follows: at diagnosis (e.g., D-80), just before allo-HSCT, prior to the conditioning (D0) and after allo-HSCT, i.e. on D+30, D+60, D+90, D+150 and later post-transplant. The bone marrow sampling was obligatory in cases of PTR occurrence. A median follow-up time after HSCT was 7 months (range from 0.6 to 52.5). The analysis of $B A A L C$ gene expression included a total of 93 samples tested at clinical (cytologically proven) relapse, and 299 specimens were taken during clinical remission. In parallel, the WT1 gene expression levels and blast cell counts were determined in each sample at the same time points. A basal BAALC expression level of $31 \%$ to the reference gene was chosen as a common cut-off value to study clinical significance of $B A A L C$ gene overexpression before and after HSCT, in order to perform molecular monitoring of leukemic precursors and interaction of blast cell populations. This value was higher than the maximal BAALC gene expression in those patients with pre-transplant cytological remission who did not show any clinical signs of the disease progression. The copy numbers $(\mathrm{CN})$ of WT1 transcripts was determined by the same quantitative real-time PCR method, according to recommendations of European LeukemiaNet group [24]. The basal WT1 expression level of 250 copies per $10^{4}$ copies of $A B L 1$ reference gene was applied to designate low and high WT1 expressors. 


\section{Statistical analysis}

Descriptive statistics methods for data with asymmetric distribution were used, with evaluation of the sample ranges and median values. Two-year relapse-free survival (RFS) and cumulative incidence of relapse (CIR) were calculated using Kaplan-Meier method, and the log-rank test was used to compare differences between survival curves. RFS and CIR were measured from D0 until the date of death, regardless of cause, or until terms of documented relapse, or last contact date. $\mathrm{P}<0.05$ was considered a statistically significant difference level. SPSS software version 22.0 (IBM corporation, Armonk, NY, USA) was used for statistical analysis.

\section{Results}

Initially, we estimated clinical significance of the BAALC gene overexpression in AML patients with a false cytological remission at the moment of transplantation. A term of "misleading" cytological remission was used to refer to clinical state with elevated WT1 expression level (higher than 250 copies per $10^{4}$ copies of reference gene $A B L 1$ ) combined

\section{A}

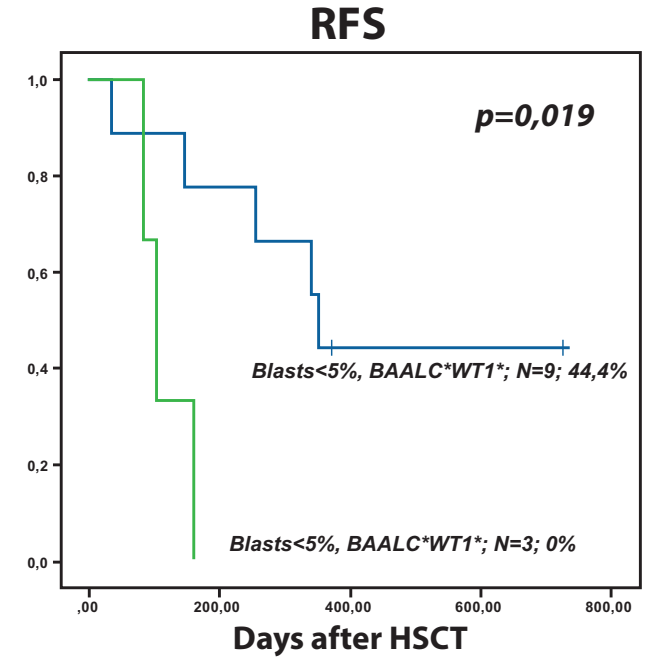

B

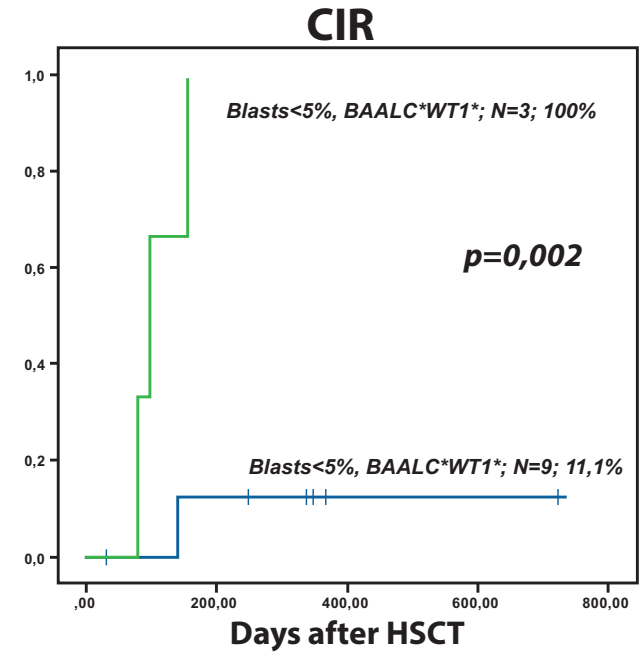

Figure 1. The difference between RFS (A) and CIR (B) depending on the BAALC gene expression level at the moment of allo-HSCT in the group of patients transplanted in a "misleading" cytological remission with normal marrow blast counts (less than 5\%). Among 12 such cases, nine patients (75\%) did not express BAALC at the levels above the chosen cut-off of $31 \%$, whereas increased $B A A L C$ expression was detected in three other patients. Despite limited number of tested AML cases, the RFS and CIR in the latter group appeared to be significantly worse, compared to those with low BAALC expression ( $\mathrm{p}=0.019$ и $\mathrm{p}=0.002$, respectively), as seen from Fig. 1 .

Hence, one may conclude that the patients with combined WT1 and BAALC overexpression could be classified into prognostically unfavorable group, associated with high risk of early post-transplant relapse. This regulatory function seems to be retained in nine patients studied at the moment of transplantation. However, it could be lost in three other patients, in whom a combined $W T 1$ and BAALC overexpression took place.

The BAALC and WT1 expression levels for the previously discussed AML patients [23] were assessed in the context of our recent findings. As shown in Fig. 2, the highest BAALC expression levels were observed in relapsing patients with AML classified as M1 and M2 FAB-variants, with intermediate values in M0, M4 and M5 FAB-variants of AML. The lowest BAALC expression was detected in AML M3 and M7 cases.

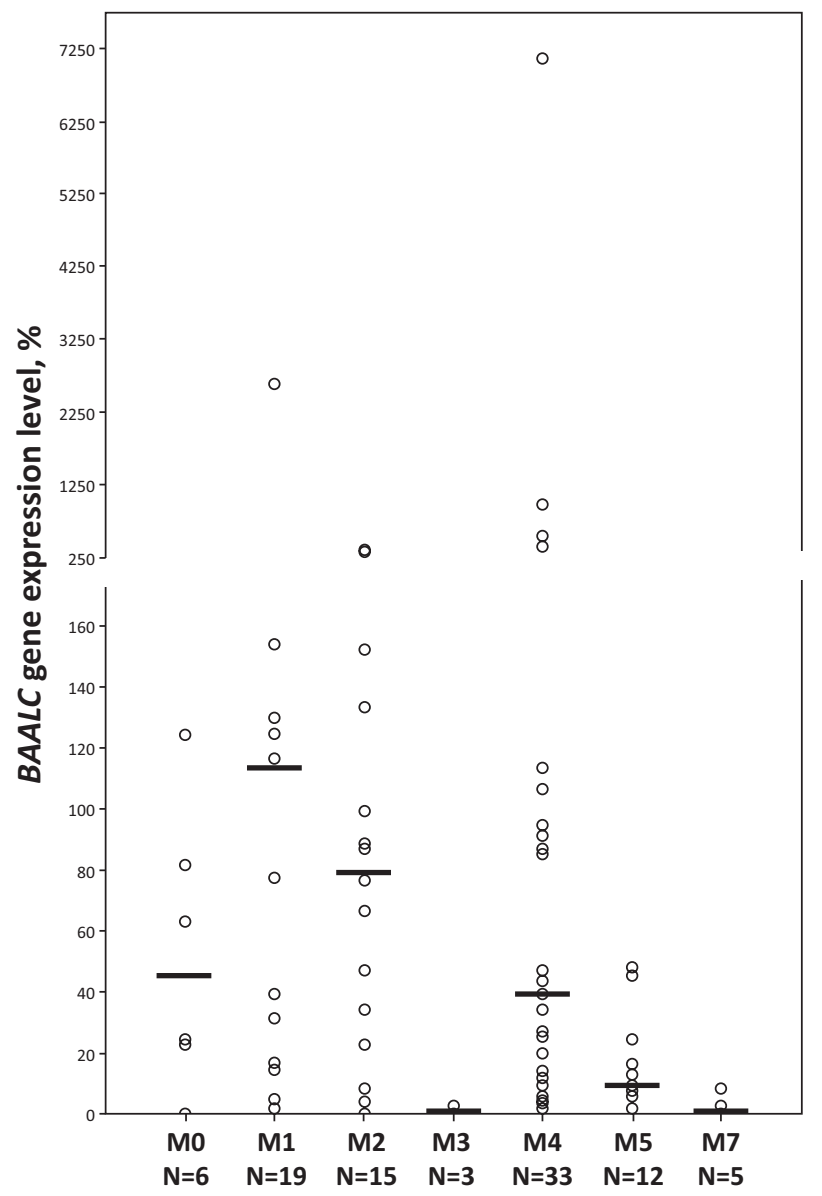

Figure 2. Distribution of individual values and median levels of BAALC gene expression in relapsing patients with different $A M L$ FAB-variants 
In addition, we have studied the BAALC gene expression levels in patients with different cytogenetic AML variants. According to our data, the highest BAALC gene expression levels among cases with favorable cytogenetic changes were observed in the patients with $\mathrm{t}(8 ; 21)(\mathrm{N}=21)$, and in subgroups with unfavorable karyotype, i.e., aberrations in chromosomes 5 and $7(\mathrm{~N}=23)$, as well as complex karyotype $(\mathrm{N}=8)$, and other severe abnormalities $(\leq 2)(\mathrm{N}=11$, data not shown). In cases of relapse, no statistically significant differences of BAALC gene expression levels were noted between these subgroups.

The patient cohort with higher $B A A L C$ gene expression ( $>31 \%$ in relapse) consisted of 30 out of 50 cases $(60 \%)$, including eight patients with both $\mathrm{M} 1$ and M2 FAB- variants of AML. A combined BAALC and WT1 overexpression was observed in 28 cases of 30 (93.3\%). The data on two patients with M1 and M2 FAB-variants of AML are shown below (Fig. 3, 4).

As seen from Fig. 2 and Table 2, the BAALC gene expression levels in PTR were higher in patients with AML M1 and M2, and sufficiently lower in AML M4. In order to discuss in details some special interactions between leukemic cell precursors and blast cell populations, determined by means of QR-PCR, we have demonstrated here complete clinical and laboratory characteristics from a larger group of patients with different cytological and cytogenetic AML variants according to FAB criteria. Our study cohort consisted of 22 patients ( 11 cases for each AML M1 and M2-variants). Twenty one of them had a fully characterized cell karyotype. Simultaneous overexpression of both BAALC and WT1 genes at PTR was detected in four and three AML M1 and M2 cases, respectively (Table 2). As based on these data, the presence of a combined gene overexpression in the patients at post-transplant period is considered an index of unfavorable prognosis.

As seen from Table 2, simultaneous overexpression of $B A A L C$ and $W T 1$ genes at relapse at any stage of the disease (at diagnosis, D0 pre-transplant, or PTR) occurred in 28/55 (56\%) patients. It was observed in eight patients with AML M1 (72.7\%), 8 patients with AML M2 (72.7\%), as well as in 1 (33.3\%), 8 (50\%), 2 (40\%) patients with AML M0, M4, and M5, respectively.

To illustrate this concept, several clinical cases of each AML M1, M2 and M4 FAB-variants are represented below (Fig. 3 to 5 ). The relative ratios of leukemic cell precursors or blast cell burdens were monitored as BAALC and WT1 gene expression levels, respectively, as shown for a patient with AML M1 (Table 2, Fig. 3). In this case No.4, a simultaneous $B A A L C$ and $W T 1$ overexpression took place at diagnosis, and at $2^{\text {nd }}$ and $3^{\text {rd }}$ PTRs that occured despite second HSCT and high-dose chemotherapy which was unsuccessful.

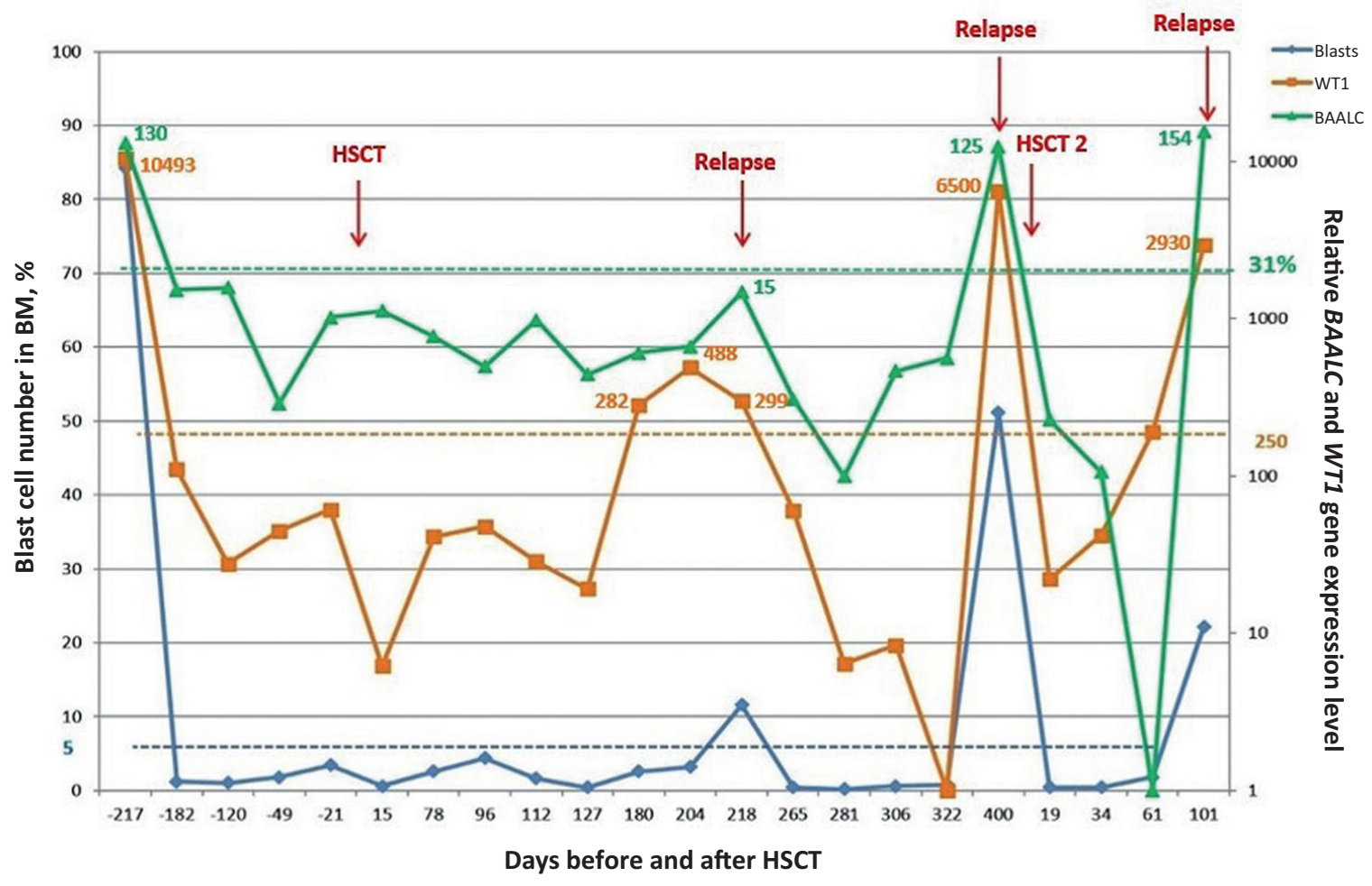

Figure 3. Monitoring of BAALC and WT7 mRNA expression levels measured by QR-PCR, and bone marrow blast numbers in a patient with AML MI (№4)

The values of molecular indexes $\left(\mathrm{CN}_{\text {gene }} / 10^{4}{ }_{\text {ABL1 }}\right)$ in relapse before allo-HSCT and during 1 to 3 PTRs were $1.3 ; 0.15 ; 1.25 ; 1.54$ for $B A A L C$ gene, and 1.05; 0.03; 0.05 and 0.03 for the WT1 gene, respectively. Abscissa, terms of observation pre- and post-transplant, Ordinate, blast numbers (left axis); gene expression (right axis). 
Table 2. BAALC and WTI gene expression levels at diagnosis, before allo-HSCT (D0) and at PTRs after hematopoietic stem cell transplantation in the patients with different AML FAB-variants

\begin{tabular}{|c|c|c|c|c|c|c|c|c|c|c|c|c|c|c|c|c|}
\hline \multirow{3}{*}{ № } & \multirow{3}{*}{ FAB } & \multirow{3}{*}{ Gender } & \multirow{3}{*}{$\begin{array}{l}\text { Age, } \\
\text { years }\end{array}$} & \multicolumn{9}{|c|}{ Disease stage } & \multirow{3}{*}{$\begin{array}{l}\text { PTR } \\
\text { day }\end{array}$} & \multirow{3}{*}{$\begin{array}{l}\text { Clinical stages } \\
\text { with coupled } \\
\text { BAALC+ and WT1+ } \\
\text { overexpression }\end{array}$} & \multirow{3}{*}{$\begin{array}{l}\text { Out- } \\
\text { come }\end{array}$} & \multirow{3}{*}{$\begin{array}{l}\text { OS, } \\
\text { days }\end{array}$} \\
\hline & & & & \multicolumn{3}{|c|}{ Diagnosis } & \multicolumn{3}{|c|}{ DO } & \multicolumn{3}{|c|}{ PTR } & & & & \\
\hline & & & & $\begin{array}{l}\text { BAALC } \\
\%\end{array}$ & WT1+ & \begin{tabular}{|l} 
Blasts \\
$\%$
\end{tabular} & $\begin{array}{l}\text { BAALC } \\
\%\end{array}$ & WT1+ & $\begin{array}{l}\text { Blasts } \\
\%\end{array}$ & $\begin{array}{l}\text { BAALC } \\
\%\end{array}$ & WT1+ & $\begin{array}{l}\text { Blasts } \\
\%\end{array}$ & & & & \\
\hline 1 & MI & $\mathrm{m}$ & 21 & $n / d$ & $n / d$ & $n / d$ & 0.5 & 379 & 2.5 & 329 & 7858 & 70 & 146 & PTR & Died & 306 \\
\hline 2 & MI & $f$ & 48 & 17 & 386 & 60 & $n / d$ & $n / d$ & $n / d$ & 117 & 281 & 40 & 61 & PTR & Died & 98 \\
\hline 3 & M1 & $\mathrm{f}$ & 54 & $n / d$ & $n / d$ & $n / d$ & 32 & 18439 & 79.2 & 77 & 32981 & 35.4 & 24 & D0, PTR & Died & 61 \\
\hline 4 & MI & $f$ & 26 & 130 & 10493 & 84.2 & $n / d$ & $n / d$ & $n / d$ & 125 & 6500 & 11.6 & 400 & Diagnosis, PTR & Died & 692 \\
\hline 5 & MI & $f$ & 60 & 2617 & 1728 & 96.6 & 3 & 29 & 0.6 & 378 & 197 & 37 & 155 & Diagnosis & Died & 382 \\
\hline 6 & MI & $f$ & 18 & 370 & 402 & 32 & $n / d$ & $n / d$ & $n / d$ & - & - & - & - & Diagnosis & Died & 95 \\
\hline 7 & MI & $\mathrm{m}$ & 18 & 242 & 13542 & 93.2 & $n / d$ & $n / d$ & $n / d$ & - & - & - & - & Diagnosis & Live & 730 * \\
\hline 8 & MI & $f$ & 25 & $n / d$ & $n / d$ & $n / d$ & 40 & 1764 & 13.2 & - & - & - & - & DO & Died & 613 \\
\hline 9 & MI & $f$ & 44 & $n / d$ & $n / d$ & $n / d$ & 29 & 2355 & 8.8 & $n / d$ & $n / d$ & $n / d$ & 21 & - & Died & 45 \\
\hline 10 & MI & $f$ & 32 & $n / d$ & $n / d$ & $n / d$ & 21 & 40 & 2 & 4 & 41 & 7.8 & 98 & - & Live & 672 \\
\hline 11 & MI & $\mathrm{m}$ & 26 & $n / d$ & $n / d$ & $n / d$ & 2 & 47 & 2.6 & 2 & 35 & 48 & 143 & - & Died & 179 \\
\hline 12 & M2 & $\mathrm{m}$ & 30 & 4 & 725 & 26.8 & $n / d$ & $n / d$ & $n / d$ & 153 & 2363 & 23 & 53 & PTR & Died & 194 \\
\hline 13 & M2 & $f$ & 15 & 89 & 37 & 71.2 & 34 & 322 & 9 & 67 & 2033 & 45 & 67 & D0, PTR & Died & 306 \\
\hline 14 & M2 & $\mathrm{m}$ & 39 & $n / d$ & $n / d$ & $n / d$ & $n / d$ & $n / d$ & $n / d$ & 83 & 18872 & 26 & 77 & PTR & Died & 350 \\
\hline 15 & M2 & $f$ & 38 & $n / d$ & $n / d$ & $n / d$ & 787 & 8756 & 59.4 & - & - & - & - & $\mathrm{DO}$ & Died & 407 \\
\hline 16 & M2 & $\mathrm{m}$ & 58 & $n / d$ & $n / d$ & $n / d$ & 366 & 26100 & 45.8 & $n / d$ & $n / d$ & $n / d$ & 763 & DO & Died & 763 \\
\hline 17 & M2 & $\mathrm{m}$ & 35 & $n / d$ & $n / d$ & $n / d$ & 34 & 4238 & 5 & - & - & - & - & $\mathrm{DO}$ & Died & 20 \\
\hline 18 & M2 & $\mathrm{m}$ & 8 & 321 & 1236 & 69.6 & 22 & 7 & 4.2 & - & - & - & - & Diagnosis & Live & 469 \\
\hline 19 & M2 & $\mathrm{m}$ & 9 & 99 & 10789 & 21.2 & 27 & 4 & 1.6 & - & - & - & - & Diagnosis & Live & 730 * \\
\hline 20 & M2 & $\mathrm{m}$ & 28 & $n / d$ & $n / d$ & $n / d$ & $n / d$ & $n / d$ & $n / d$ & 23 & 5518 & 24 & 68 & - & Died & 162 \\
\hline 21 & M2 & $f$ & 49 & $n / d$ & $n / d$ & $n / d$ & 14 & 4 & 6.5 & $n / d$ & $n / d$ & $n / d$ & 188 & - & Died & 214 \\
\hline 22 & M2 & $\mathrm{m}$ & 15 & 0.6 & 37 & 8.8 & $n / d$ & $n / d$ & $n / d$ & - & - & - & - & - & Live & $730^{*}$ \\
\hline 23 & M0 & $f$ & 42 & $n / d$ & $n / d$ & $n / d$ & 521 & 8296 & 14 & $n / d$ & $n / d$ & $n / d$ & 138 & DO & Died & 166 \\
\hline 24 & M0 & $\mathrm{m}$ & 25 & 124 & 2.5 & 84.6 & $n / d$ & $n / d$ & $n / d$ & 82 & 5 & 28.2 & 98 & - & Died & 103 \\
\hline 25 & M0 & $f$ & 12 & 0.01 & 11168 & 99 & $n / d$ & $n / d$ & $n / d$ & $n / d$ & $n / d$ & $n / d$ & 112 & - & Died & 129 \\
\hline 26 & M4 & $\mathrm{m}$ & 6 & 982.1 & 183 & 54.6 & $n / d$ & $n / d$ & $n / d$ & 7118 & 296 & 41.2 & 246 & PTR & Died & 779 \\
\hline 27 & M4 & $\mathrm{f}$ & 34 & $n / d$ & $n / d$ & $n / d$ & 549 & 10819 & 11.6 & $n / d$ & $n / d$ & $n / d$ & 526 & $\mathrm{DO}$ & Died & 560 \\
\hline 28 & M4 & $\mathrm{m}$ & 39 & $n / d$ & $n / d$ & $n / d$ & 503 & 3548 & 62 & - & - & - & - & DO & Live & 614 \\
\hline 29 & M4 & $f$ & 21 & 107 & 867 & 17 & $n / d$ & $n / d$ & $n / d$ & 389 & 529 & 12 & 83 & Diagnosis, PTR & Died & 393 \\
\hline 30 & M4 & $f$ & 25 & 107 & 1790 & 82 & $n / d$ & $n / d$ & $n / d$ & - & - & - & - & Diagnosis & Live & $730^{*}$ \\
\hline 31 & M4 & $\mathrm{m}$ & 5 & 95 & 999 & 65.8 & $n / d$ & $n / d$ & $n / d$ & 35 & 411 & 12.6 & 223 & Diagnosis, PTR & Live & $730^{*}$ \\
\hline 32 & M4 & $\mathrm{m}$ & 21 & $n / d$ & $n / d$ & $n / d$ & 39 & 41 & 5.4 & - & - & - & - & - & Live & 518 \\
\hline 33 & M4 & $f$ & 28 & $n / d$ & $n / d$ & $n / d$ & 34 & 7367 & 7.6 & $n / d$ & $n / d$ & $n / d$ & 195 & DO & Live & $730^{*}$ \\
\hline 34 & M4 & $\mathrm{f}$ & 16 & 34 & 1479 & 22.5 & $n / d$ & $n / d$ & $n / d$ & - & - & - & - & Diagnosis & Died & 128 \\
\hline 35 & M4 & $\mathrm{m}$ & 19 & 27 & 14929 & 95 & 9 & 1319 & 25.4 & - & - & - & - & - & Died & 311 \\
\hline 36 & M4 & $f$ & 19 & $n / d$ & $n / d$ & $n / d$ & 25 & 96 & 10.6 & - & - & - & - & - & Live & $730^{*}$ \\
\hline 37 & M4 & $\mathrm{m}$ & 27 & $n / d$ & $n / d$ & $n / d$ & 20 & 1696 & 10 & - & - & - & - & - & Died & 459 \\
\hline 38 & M4 & $\mathrm{m}$ & 18 & $n / d$ & $n / d$ & $n / d$ & 10 & 836 & 7.2 & - & - & - & - & - & Died & 61 \\
\hline 39 & M4 & $\mathrm{m}$ & 17 & $n / d$ & $n / d$ & $n / d$ & 5 & 51 & 3 & 6 & 362 & 7 & 99 & - & Died & 197 \\
\hline 40 & M4 & $f$ & 55 & 4 & 11686 & 68 & $n / d$ & $n / d$ & $n / d$ & 0.06 & 1020 & 20 & 57 & - & Died & 101 \\
\hline 41 & M4 & $\mathrm{m}$ & 17 & $n / d$ & $n / d$ & $n / d$ & 2 & 2258 & 12 & - & - & - & - & - & Live & $730 *$ \\
\hline 42 & M5 & $f$ & 32 & $n / d$ & $n / d$ & $n / d$ & 272 & 3779 & 31.6 & - & - & - & 23 & DO & Died & 142 \\
\hline 43 & M5 & $\mathrm{m}$ & 11 & 45 & 11753 & 88 & $n / d$ & $n / d$ & $n / d$ & - & - & - & - & Diagnosis & Live & $730^{*}$ \\
\hline 44 & M5 & $\mathrm{m}$ & 37 & 2 & 177 & 8 & 2 & 77 & 3.8 & 24 & 4542 & 21 & 195 & - & Died & 423 \\
\hline 45 & M5 & $\mathrm{m}$ & 22 & 17 & 25 & 94.4 & 0.6 & 6 & 1.4 & 10 & 25 & 9.6 & 42 & - & Live & $730^{*}$ \\
\hline 46 & M5 & $\mathrm{m}$ & 55 & 1.3 & 9631 & 40 & $n / d$ & $n / d$ & $n / d$ & - & - & - & - & - & Live & $730 *$ \\
\hline 47 & M3 & $f$ & 17 & $n / d$ & $n / d$ & $n / d$ & $n / d$ & $n / d$ & $n / d$ & 3 & 32684 & 24.4 & 136 & - & Died & 160 \\
\hline 48 & M3 & $\mathrm{m}$ & 18 & 0.053 & 4375 & 33.6 & $n / d$ & $n / d$ & $n / d$ & - & - & - & - & - & Live & $730^{*}$ \\
\hline 49 & M7 & $\mathrm{f}$ & 3 & 0.25 & 282 & 12.8 & 3 & 3693 & 13.4 & 0,3 & 1049 & 20.8 & 60 & - & Died & 258 \\
\hline 50 & MDS & $\mathrm{m}$ & 8 & $n / d$ & $n / d$ & $n / d$ & 51 & 2048 & 7.2 & 121 & 10239 & 30.4 & 181 & D0, PTR & Died & 317 \\
\hline
\end{tabular}

n/d - no data; - - no PTR; * - censored; $2^{\text {nd }}$ - secondary AML developed from MDS; +, mean of WT1 copies $/ 10^{4}$ copies of ABL1 gene 
In this case, cytogenetic characteristics of leukemic cells were different for the $1^{\text {st }}$ and $2^{\text {nd }}$ relapses. At the first PTR, complex karyotype changes included loss of chromosome $\mathrm{X}$, deletion of $11 \mathrm{q}$ and additional chromosome 21 revealed in $15 \%$ of tested cells, whereas additional unbalanced translocations $\mathrm{t}(\mathrm{X} ; 17), \mathrm{t}(1 ; 3)$, and $\mathrm{t}(1 ; 17)$ were detected in the second PTR.

In another AML case No. 12 (M2 variant) with $\mathrm{t}(8 ; 21)$ translocation (Fig. 4), a simultaneous measurement of BAALC and $W T 1$ gene expression levels revealed overexpression of the WT1 gene at diagnosis, with bone marrow blast burden of up to $28 \%$. Further on, a combined overexpression of both molecular markers was associated with $1^{\text {st }}$ and $2^{\text {nd }}$ relapses, thus being prognostically unfavorable. One may suggest that the disease progression and fatal outcome occurred due to resistance of tumor cells to therapy.

Similar clinical situation was observed in the next patient with AML M4 (No. 31), who received allotransplant at the age of five years. In spite of $t(8 ; 21)$ translocation found at diagnosis, thus classifying the patient into favorable group, an additional deletion $7 \mathrm{q}-\operatorname{del}(7)(\mathrm{q} 32 \mathrm{q} 36)$ before transplant allowed, however, to evaluate this case as unfavorable one. The combined BAALC and WT1 overexpression at diagnosis, as well as in first PTR, was accompanied by increased expression level of a specific RUNX1/RUNX1T1 fusion transcript (Fig. 5). Of notice, the blast burden in the bone marrow sample at relapse $(D+223)$ was not too high, wherein hypothetic inhibition of leukemic precursor cells from side of the blast population was minimal, thus explaining higher $B A A L C$ gene expression levels observed.

Another clinical case (No. 29) concerns a female patient 21 years old with AML M4 FAB variant (Fig. 6). The first concomitant overexpression of BAALC and WT1 genes has been observed pre-transplant, associated with complex structural chromosomal changes, i.e., monosomy $7, \mathrm{t}(2 ; 3)$ translocation, as well as $3 \mathrm{q}$ inversion. All these abnormalities seemed to correlate with a failure to achieve full cytological and molecular remissions. It has been combined with overexpression of both BAALC and WT1 genes during the entire posttransplant period. From this point of view, it is not surprising that the first PTR occurred early on D+80 after transplantation. Prognostically unfavorable simultaneous WT1 and $B A A L C$ overexpression, as well as the same clonal changes of karyotype were detected again at that time. The second clinical relapse was detected on the day D+232 posttransplant, when overexpression of the both genes was expressed even more, and a new additional chromosomal abnormality (monosomy 5) was detected on day D+251.

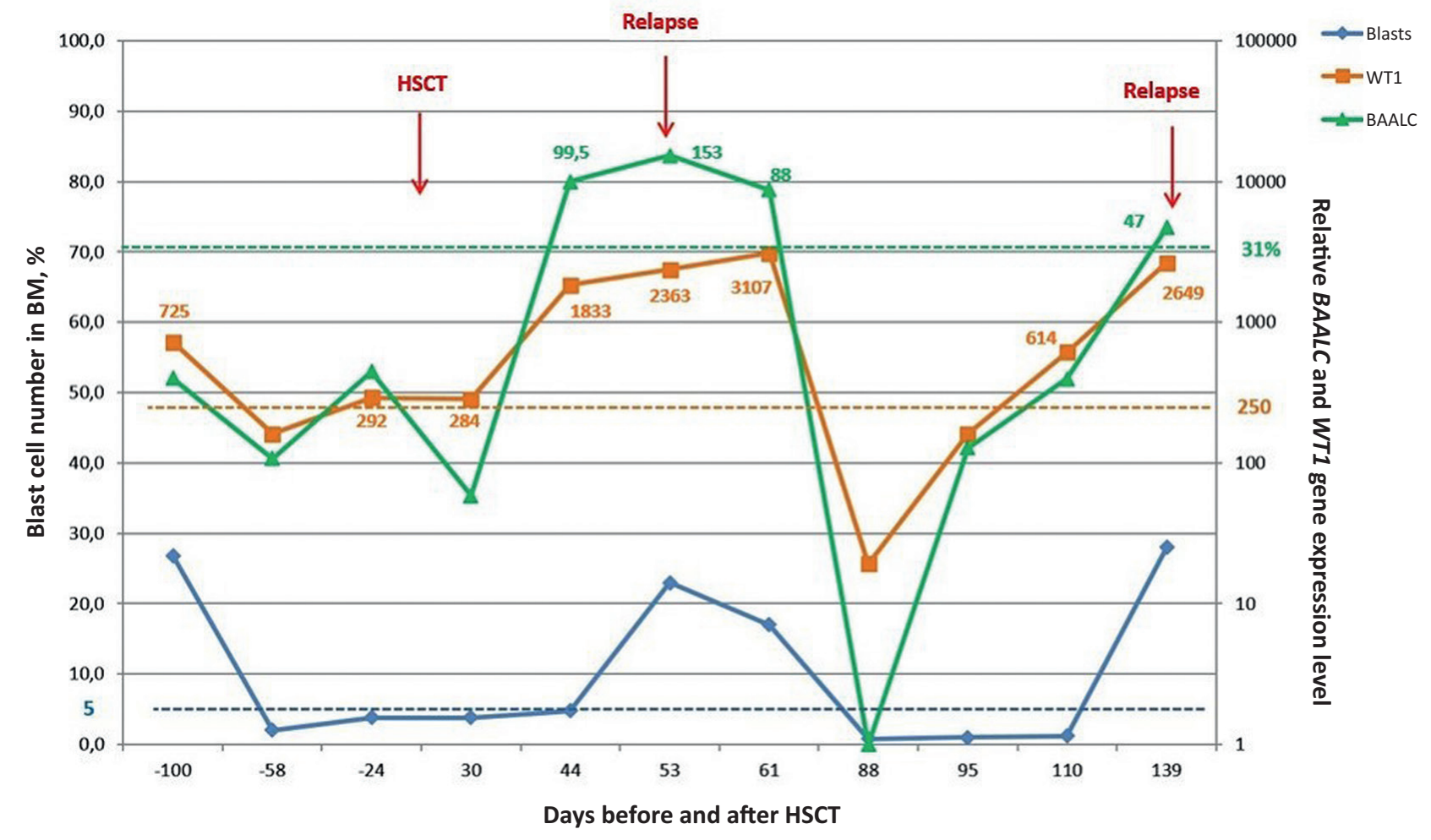

Figure 4. Molecular monitoring of the interaction between leukemic cell precursor and blast cell masses in young patient with AML M2 (№ 12) measured by QR-PCR of BAALC and WT1 mRNA expression levels

Values of molecular indexes $\left(\mathrm{CN}_{\text {gene }} / 10^{4}{ }_{\text {ABL1 }}\right)$ in relapse before allo-HSCT and in two PTRs were $0.04 ; 1.5 ; 0.47$ for gene BAALC and $0.07 ; 0.24 ; 0.27$ for gene $W T 1$, respectively. Abscissa, terms of observation pre- and post-transplant, Ordinate, blast numbers (left axis); gene expression (right axis). 

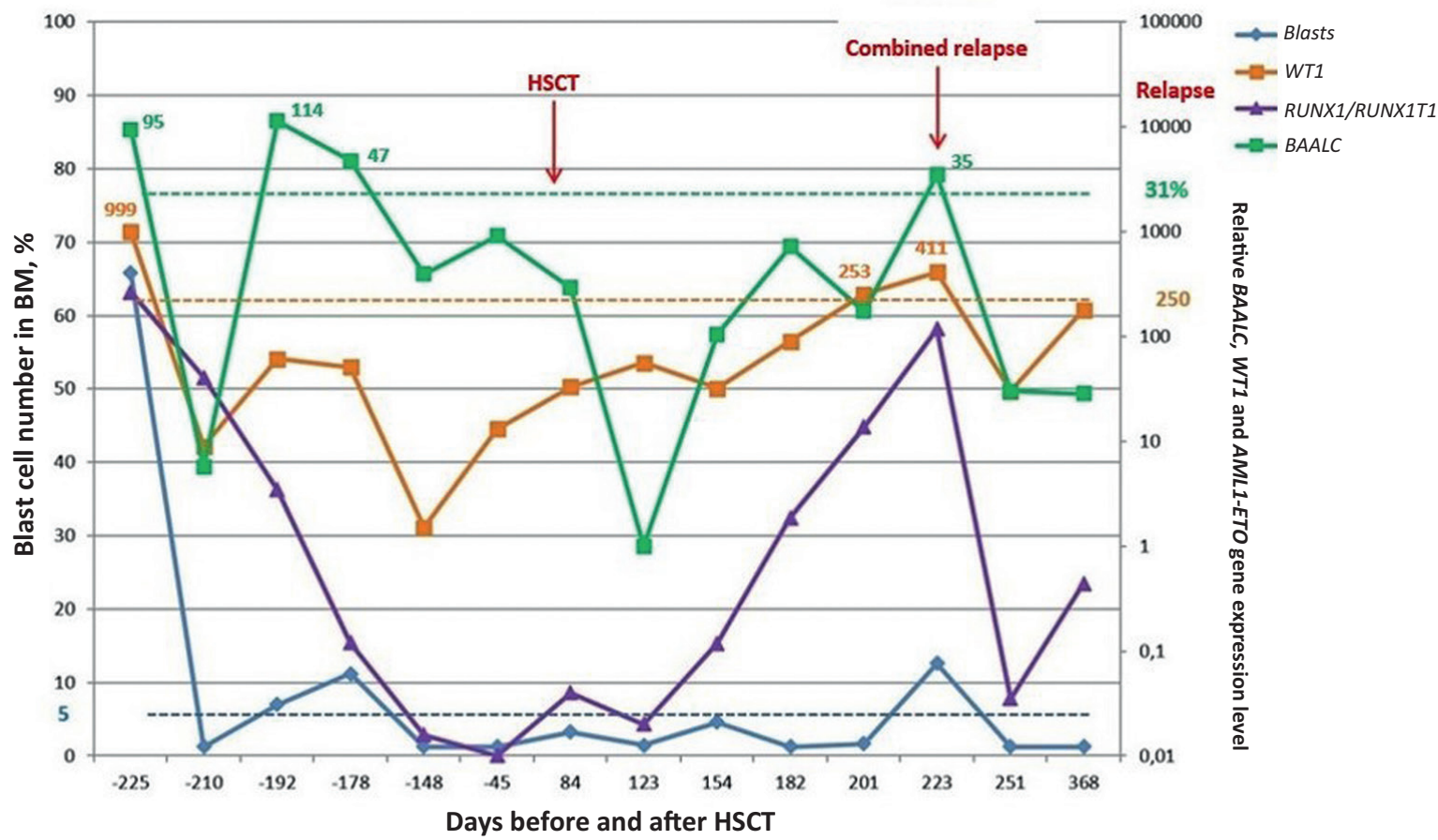

$=$ BAALC

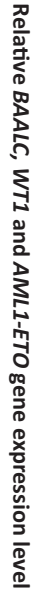

Figure 5. Molecular monitoring of interactions between leukemic cell precursors and blast cells in the patient with AML M4 (№ 31) measured by QR-PCR of BAALC, WT7 and RUNX1/RUNXIT1 gene expression levels

Values of molecular indexes $\left(\mathrm{CN}_{\text {gene }} / 10^{4}{ }_{\mathrm{ABL} 1}\right)$ in relapse before allo-HSCT and in PTR were 0.95; 0.35 for gene BAALC and 0.1; 0.04 for gene $W T 1$, respectively. Abscissa, terms of observation pre- and post-transplant, Ordinate, blast numbers (left axis); gene expression (right axis).

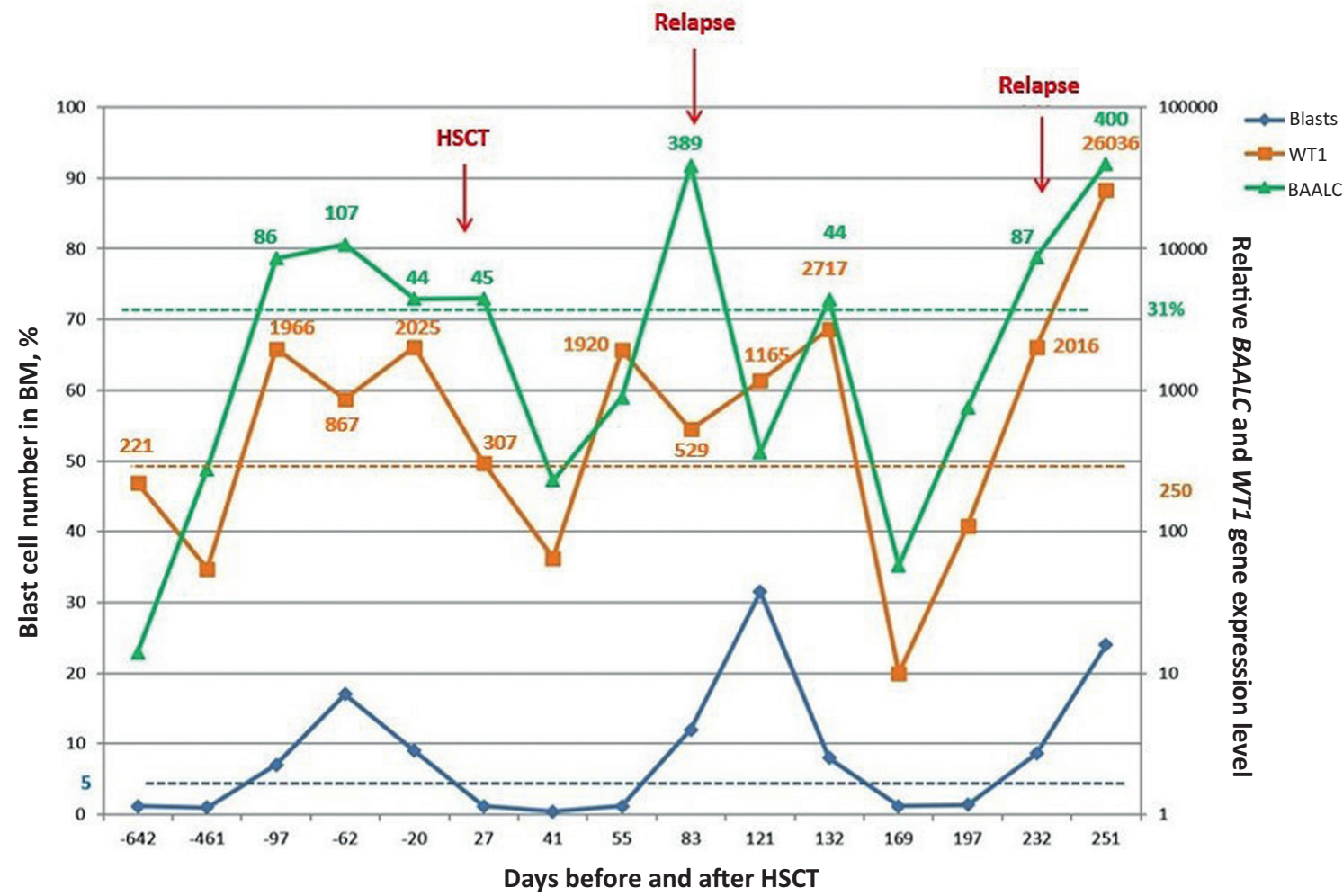

Figure 6. Molecular monitoring of the interaction between leukemic cell precursors and blast cells burdens in patient with AML M4 (№ 29) measured by OR-PCR of BAALC and WT1 gene expression levels

Values of molecular indexes $\left(\mathrm{CN}_{\text {gene }} / 10^{4}{ }_{\mathrm{ABL} 1}\right)$ in relapse before allo-HSCT and in two PTRs were 1.07; 3.9; 4 for gene BAALC and $0.09 ; 0.12 ; 2.6$ for gene WT1, respectively. Abscissa, terms of observation pre- and post-transplant, Ordinate, blast numbers (left axis); gene expression (right axis). 
Another molecular profile has been revealed during serial measurement of BAALC and WT1 gene expression levels in a 55-year old female patient (Case No. 40, Table 2) with the same AML M4 FAB-variant, but with normal karyotype (Fig. 7). As shown here, the elevated WT1 gene expression level took place not only in pre-transplant relapse, but in early PTR as well, which seems to be a result of transplantation without subsequent cytological remission. At the same time, the BAALC gene overexpression was not observed at neither of relapses. Instead of successful treatment of the first PTR at D+65 after allo-HSCT, the patient developed a new cytological relapse accompanied by the WT1 gene overexpression, and the lethal outcome was detected at D+101 after allo-HSCT.

As regards special AML forms, characterized by the absence of BAALC overexpression we observed in 4 (8\%) of 50 such cases in our cohort (three among them had AML M3 and one, M7 FAB-variant). Data of the serial parallel measurement of BAALC and WT1 gene expression levels in one of them are represented at Figure 8. Elevated BAALC gene expression level over the cut-off level in a 17 -year-old female patient (№ 47) was not observed both at relapse before allo-HSCT, or in posttransplant relapse. At the same time, a significant WT1 gene overexpression took place in both relapses.

In general, the results shown in Fig. 8 may be explained by more differentiated state of promyelocytes providing clinical development of acute promyelocytic leukemia, compared to CD34+/CD38- cell precursors of leukemic hematopoiesis.
By this reason, they are unable to express $B A A L C$ gene. On the other hand, some, still unknown, immature leukemic cells in M3 FAB- variant AML must have a direct cause higher WT1 gene expression levels which should be studied at regular basis.

It is reasonable to present here some data on parallel measurement of BAALC and WT1 gene expression level in bone marrow samples from a 3-year-old female patient (№ 49) with AML M7 (Fig. 9). The BAALC gene expression level was under the cut-off value during the entire follow-up period. At the same time, WT1 gene overexpression closely associated with increasing blast burden in bone marrow, was detected during relapse before HSCT, as well as at the posttransplant relapse with pronounced blastosis in bone marrow (>60\%).

Finally, we would like to demonstrate here some special biological features of blast elements in AML patients, who did not exhibit WT1 gene overexpression. E.g., we present the graphs of molecular monitoring by $W T 1$ and $B A A L C$ expression levels in two patients (No. 24 and 26) with M0 AML (Fig. 10) and M4 AML (Fig. 11). The first case presents a 25-year old patient (№ 24), who had reciprocal translocation $\mathrm{t}(3 ; 10)(\mathrm{p} 21 ; \mathrm{p} 11)$ (without EVI1 gene overexpression), and interstitial deletion of chromosome 11 long arm (without MLL gene rearrangements, as shown by FISH technique). According to this graph, the BAALC gene expression level over the cut-off value was detected at relapse before transplantation, as well as at PTR, whereas WT1 gene expression level changes were $<250$ copies per $10^{4}$ copies of $A B L 1$ gene during entire period of study. The lethal outcome of the disease on the D+133 after transplantation has been associated with progression.

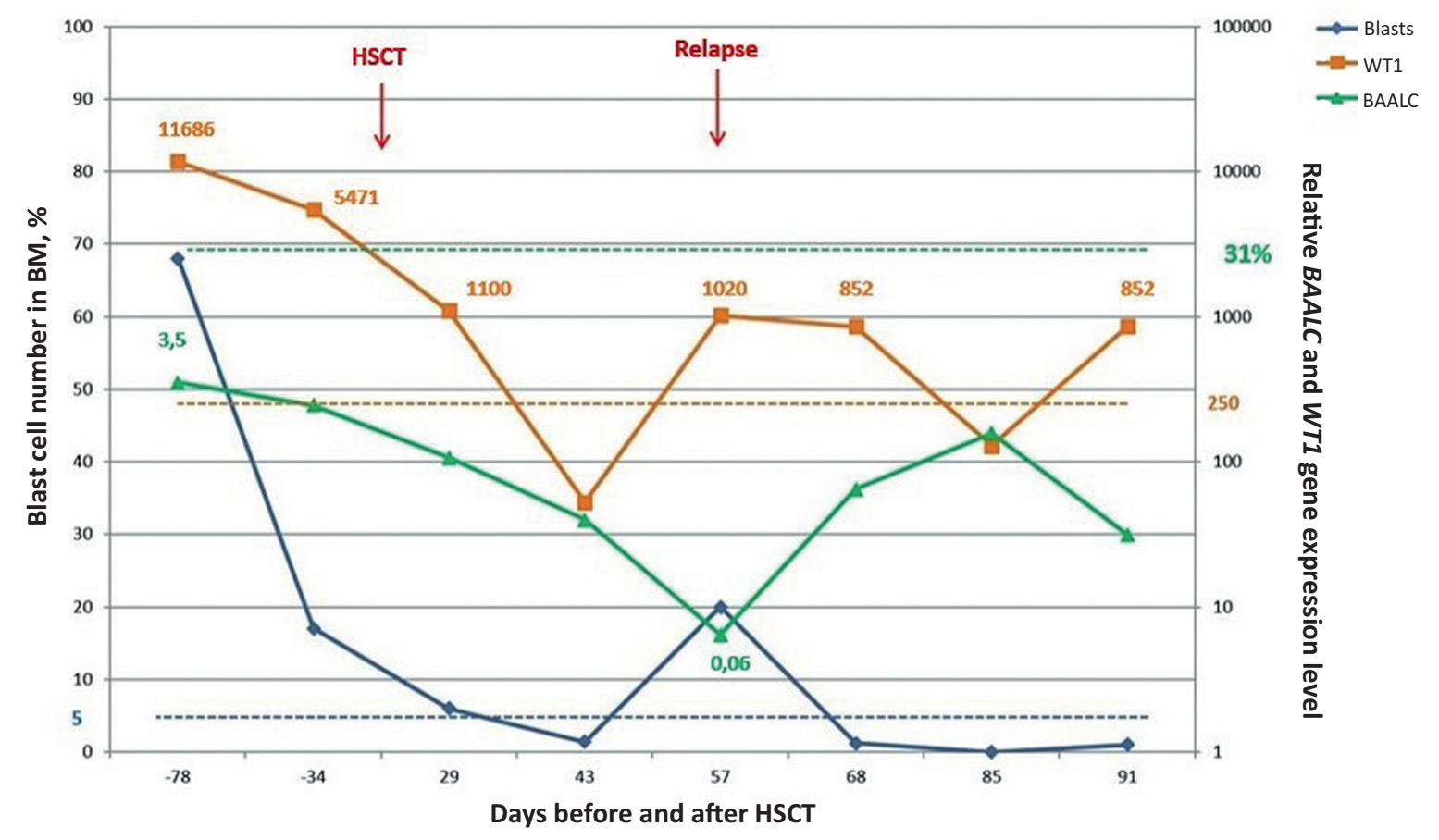

Figure 7. Molecular monitoring of the interaction between leukemic cell precursor and blast cell masses in patient with AML M4 (№ 40) measured by OR-PCR of BAALC and WTI gene expression levels

Values of molecular indexes $\left(\mathrm{CN}_{\text {gene }} / 10^{4}{ }_{\text {ABL1 }}\right)$ in relapse before allo-HSCT and in PTR were 0.035; 0.0006 for gene BAALC and 1.17; 0.1 for gene WT1, respectively. Abscissa, terms of observation pre- and post-transplant, Ordinate, blast numbers (left axis); gene expression (right axis). 


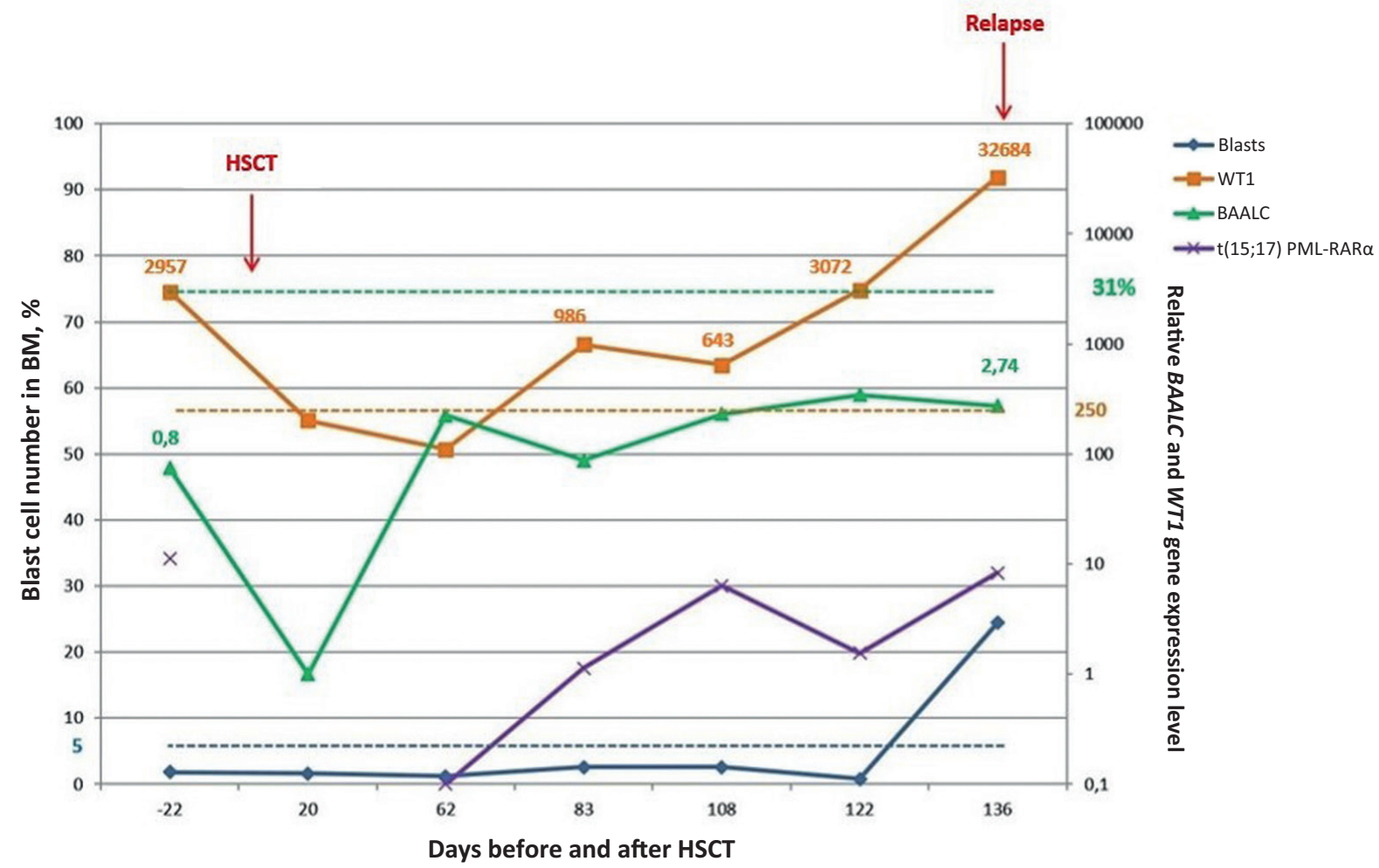

Figure 8. Molecular monitoring of the interaction between leukemic cell precursor and blast cell masses in a 17-years old female patient with AML M3 (№ 47) measured by QR-PCR of BAALC, WT7 and PML-RAR $\alpha$ gene expression levels

Values of molecular indexes $\left(\mathrm{CN}_{\text {gene }} / 10^{4}{ }_{\mathrm{ABL} 1}\right)$ in relapse before allo-HSCT and in PTR were 0.035; 0.0006 for gene BAALC and 1.17; 0.1 for gene $W T 1$, respectively. Abscissa, terms of observation pre- and post-transplant, Ordinate, blast numbers (left axis); gene expression (right axis).

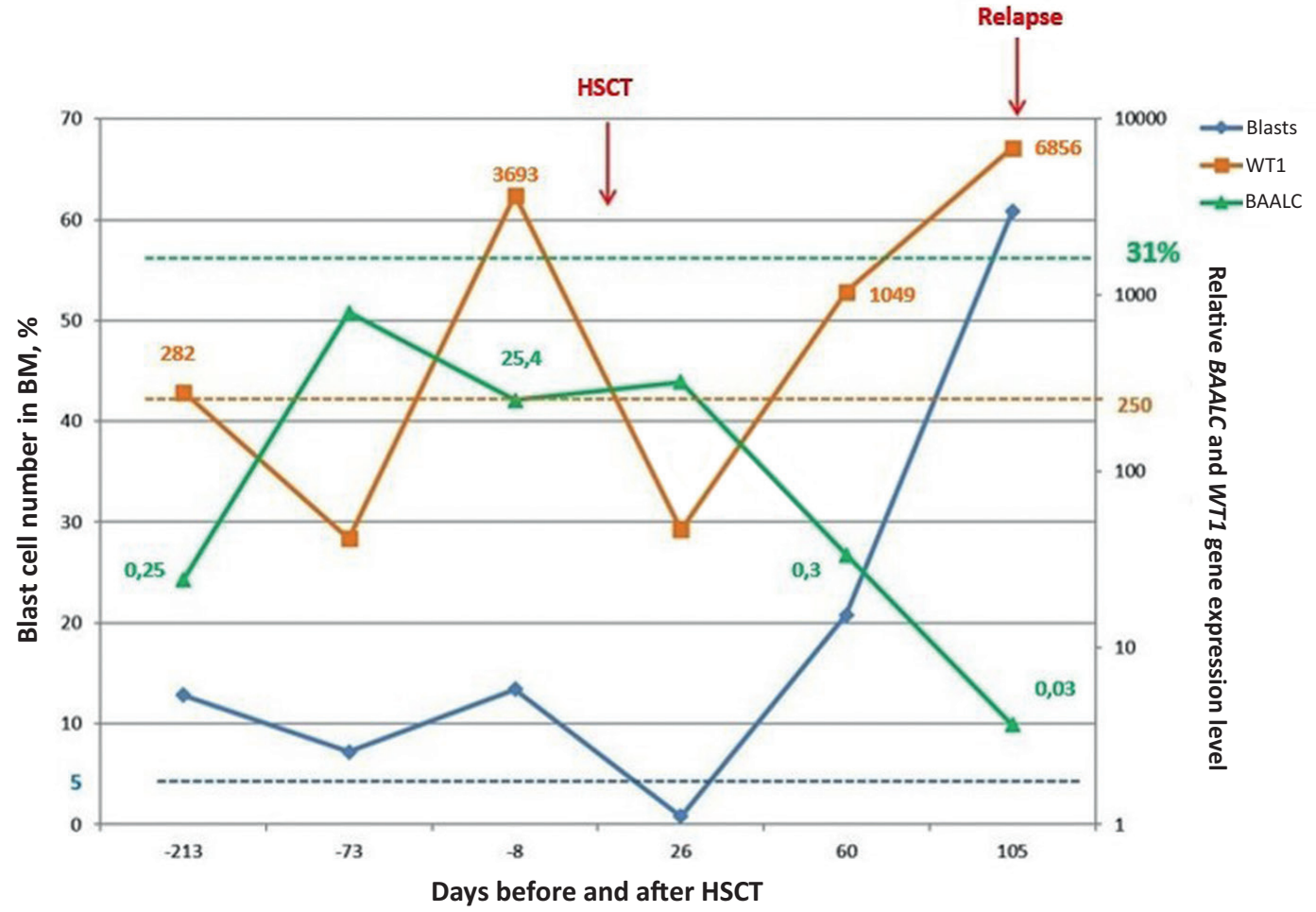

Figure 9. Molecular monitoring of the interaction between leukemic cell precursors and blast cells in a 3-years old female patient with AML M7 (№ 49) measured by QR-PCR of BAALC and WT1 gene expression levels

Values of molecular indexes $\left(\mathrm{CN}_{\text {gene }} / 10^{4}{ }_{\text {ABL1 }}\right)$ in relapse before allo-HSCT and in PTR were 0.0025; 0.0003 for gene BAALC and 0.03; 0.69 for gene WT1, respectively. Abscissa, terms of observation pre- and post-transplant, Ordinate, blast numbers (left axis); gene expression (right axis). 


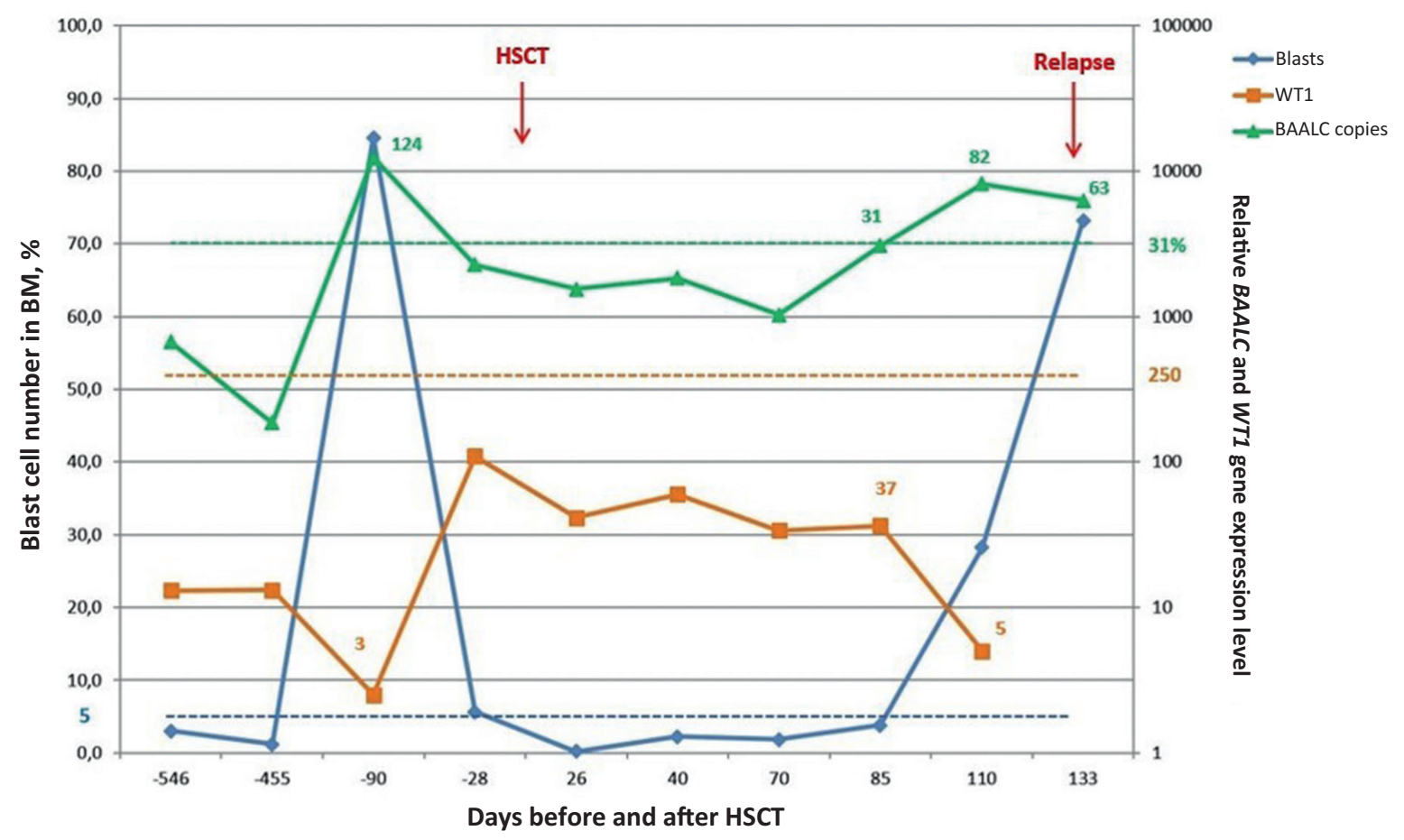

Figure 10. Molecular monitoring of the interaction between leukemic cell precursors and blast cells in a patient with AML MO (№ 24) measured by OR-PCR of BAALC and WTI gene expression levels

Values of molecular indexes $\left(\mathrm{CN}_{\text {gene }} / 10^{4}{ }_{\mathrm{ABL} 1}\right)$ in relapse before allo-HSCT and in PTR were 1.24; 0.82 for gene BAALC and 0.0003; 0.0005 for gene $W T 1$, respectively. Abscissa, terms of observation pre- and post-transplant, Ordinate, blast numbers (left axis); gene expression (right axis).

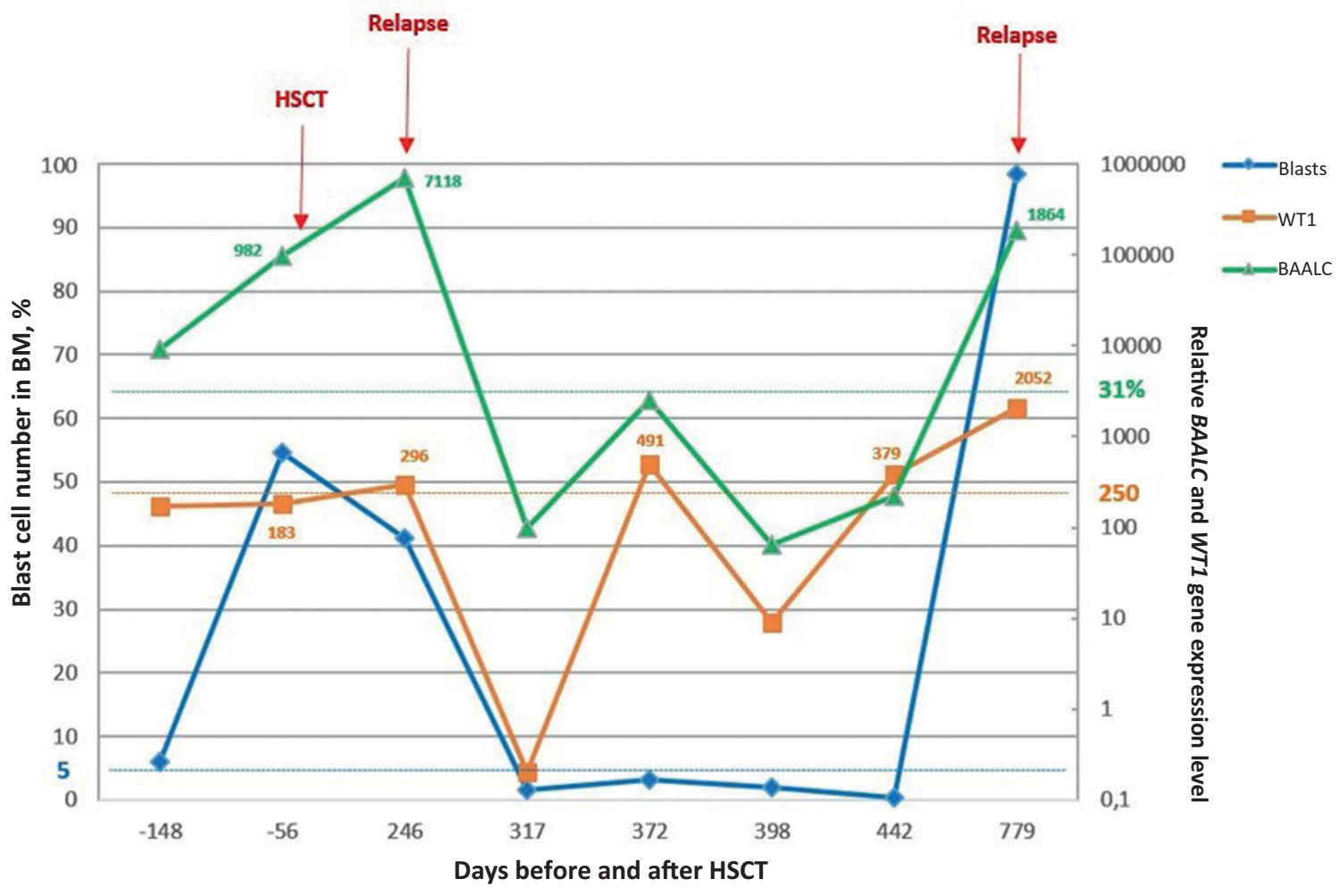

Figure 11. Molecular monitoring of the interaction between leukemic cell precursor and blast cell masses in a 6 years old patient with AML M4 (№ 26) measured by OR-PCR of BAALC and WT1 gene expression levels

Values of molecular indexes $\left(\mathrm{CN}_{\text {gene }} / 10^{4}{ }_{\mathrm{ABL} 1}\right)$ in relapse before allo-HSCT and in the first and second PTRs were 9.8; $71.2 ; 18.6$ for gene BAALC and 0.02; 0.03; 0.21 for gene WT1, respectively. Abscissa, terms of observation pre- and post-transplant, Ordinate, blast numbers (left axis); gene expression (right axis). 
The data from another clinical case are demonstrated in the Figure 11 . They relate to a 6 -years old patient, who had permanently relapsing disease course and has undergone haploidentical hematopoietic stem cell transplantation in cytological relapse for this reason. In this case, a distinct increase in $B A A L C$ expression level has been observed upon relapse before HSCT, as well as at the first PTR on the day D+246. The WT1 expression level at relapse before transplantation and at first PTR was did not exceed the cut-off level. It is equally important that, according to cytogenetic data, this patient has undergone a clonal evolution over the period between diagnosis and first PTR karyotyping associated with its transformation from normal to complex one, including rearrangements of both chromosomes 5 , as well as X, 2, 6, 9 and 19. For the first post-transplant relapse, the patient has been treated by polychemotherapy in combination with donor lymphocyte infusion and 5-azacytidin. Such supportive therapy allowed morphological remission for a sufficient period of time. However, the disease progression was detected again on the day $\mathrm{D}+734$ posttransplant, as evidenced by a combined cytological relapse with myelomonocytic blast cells. Their immune profile was as follows: CD34+/CD33+/ CD117+/CD13+/CD38+/CD14+ associated with complex clonal rearrangements of chromosomes 2, 5 and 19. It should be noted, that, at the second PTR, this patient had both BAALC and WT1 genes overexpression, what may be explained by hypothetical changes of negative regulation of leukemic precursors by the blast cell burden. Finally, lethal outcome has occurred in this case on the day D+779 post-transplant.

\section{Discussion}

The data presented here show an opportunity for simultaneous $B A A L C$ and $W T 1$ gene overexpression in a group of AML patients with increased levels of $W T 1$ and normalized up to $4 \%$ number of blasts in bone marrow samples. Therefore, it could be considered a strong indicator of poor prognosis in these cases. On the other hand, the levels of BAALC and WT1 levels expression determined by means of PCR may reflect, in a quantitative manner, the relative sizes of precursor and blast cell burden. Of note, hypothetical correlation between these tumor compartments has not elucidated yet, and may be not obligatory for all AML cases. The study has shown that the absence of BAALC overexpression at transplantation was associated with lower CIR in 9 of 12 patients (75\%) with abovementioned intermediate clinical status. On the contrary, the 3 other patients with elevated BAALC expression before transplant revealed earlier PTR development associated with shorter 2-year OS and EFS, as compared with the main group of patients. Hence, an assumption was made that simultaneous overexpression of BAALC and WT1 may be a useful indicator of dismal post-transplant AML course. Keeping this in mind, we showed a double overexpression phenomenon to be present in four patients with $\mathrm{M} 1(\mathrm{~N}=2)$, M2 $(n=1)$ and M4 (n=1) AML variants associated with poor prognosis. Further on, our data showed the levels of $B A A L C$ expression to be similarly high in patients with immature and mature M1 and M2 FAB-variants, respectively. On the other hand, the lowest BAALC expression levels were noticed in patients with M3 and M7 AML FAB- variants.
Today, the absence of $B A A L C$ gene expression in patients with acute promyelocytic leukemia may be explained by its origin from more "mature" cell populations than the standard CD34+CD38- precursors producing BAALC [25]. The same situation seems exist in the M7 FAB variants of AML, which also needs a similar additional study.

In our opinion, the results of $B A A L C$ gene expression measurement in patients with M2 and M4 FAB-variants are interesting in several regards. Firstly, high expression of $B A A L C$ and WT1 genes were synchronous in most cases. At the same time, the numbers of blast elements in their bone marrow aspirates increased to lower degree than expected. The simplest explanation for this discordance between findings in AML variants and cell maturity may be that these blast elements can differentiate only partially and, therefore, transform into more mature cellular populations. However, due to decreased size of blast population preserved in this kind of AML, some hypothetical regulating mechanisms can be activated for additional recruitment of new portions of CD34+CD38- precursors into leukemic hematopoiesis. Due to mentioned transition of blast elements to the more mature hematopoietic compartments, as well as their hypothetical regulator mechanism between blast burden and leukemic precursor compartment, the revealed similarity in gene $B A A L C$ overexpression for M2 and M4 FAB- variants of AML, and those in M1 and M0 FAB variants may be explained in these terms.

In conclusion, it should be like to notice, that clinical significance of our findings, concerning simultaneous overexpression of BAALC and WT1 genes in adults and children with AML treated with allo-HSCT, and/or donor lymphocyte infusions was presented for the first time and could be effectively used for clinical diagnostics and prediction of relapses in AML patients. The combined WT1 and BAALC overexpression was studied in relatively small group of patients, thus requiring further confirmation in larger groups of patients with different FAB variants of AML.

\section{Conflict of interest}

No conflict of interests is declared.

\section{References}

1. Tanner S, Austin J, Leone G, Rush L, Plass C, Heinonen K, Mrózek K, Still H, Knuutila S, Kolitz J, Archer K, Caligiuri $\mathrm{M}$, Bloomfield $\mathrm{C}$, de la Chapelle A. BAALC, the human member of a novel mammalian neuroectoderm gene lineage, is implicated in hematopoiesis and acute leukemia. Proc Natl Acad Sci USA. 2001;98(24):13901-13906.

2. Santamaría C, Chillón M, García-Sanz R, Pérez C, Caballero M, Mateos M, Ramos F, de Coca A, Alonso J, Giraldo P, Bernal T, Queizán J, Rodríguez J, Puig N, Balanzategui A, Sarasquete M, Alcoceba M, Díaz-Mediavilla J, San Miguel J, González M. BAALC is an important predictor of refractoriness to chemotherapy and poor survival in intermediate-risk acute myeloid leukemia (AML). Ann Hematol. 2010;89:453458. 
3. Weber S, Haferlach T, Alpermann T, Perglerová K, Schnittger S, Haferlach C, Kern W. Feasibility of BAALC gene expression for detection of minimal residual disease and risk stratification in normal karyotype acute myeloid leukemia. Br J Haematol. 2016;175(5):904-916.

4. Jentzsch M, Bill M, Grimm J, Schulz J, Goldmann K, Beinicke S, Häntschel J, Pönish W, Franke G-N, Vicinic V, Behre G, Lange T, Niederwiesser D, Schwind S. High BAALC copy numbers in peripheral blood prior to allogeneic transplantation predict early relapse in acute myeloid leukemia. Oncotarget. 2017;8(50):87994-97954.

5. Yoon J, Kim H, Shin S, Yahng S, Lee S, Cho S, Eom K, Kim Y, Lee S, Min C, Cho S, Kim D, Lee J, Min W, Park C, Lim J. BAALC and WT1 expressions from diagnosis to hematopoietic stem cell transplantation: consecutive monitoring in adult patients with core-binding-factor-positive AML. Europ J Haematol. 2013;91:112-127.

6. Xiao S, Shen J, Huang J, Fu H. Prognostic significance of the BAALC gene expression in adult patients with acute myeloid leukemia: A meta-analysis. Mol Clin Oncol. 2015;3(4):880-888.

7. Hecht A, Doll S, Altmann H, Nowak D, Lengfelder E, Röllig C, Ehninger G, Spiekermann K, Hiddemann W, Weiß C, Hofmann W, Nolte F, Platzbecker U. Validation of a molecular risk score for prognosis of patients with acute promyelocytic leukemia treated with all-trans retinoic acid and chemotherapy-containing regimens. Clin Lymphoma Myeloma Leuk. 2017; 17(12):889-896.e5.

8. Staffas A, Kanduri M, Hovland R, Rosenquist R, Ommen $\mathrm{HB}$, Abrahamsson J, Forestier E, Jahnukainen K, Jónsson ÓG, Zeller B, Palle J, Lönnerholm G, Hasle H, Palmqvist L, Ehrencrona H; Nordic Society of Pediatric Hematology and Oncology (NOPHO). Presence of FLT3-ITD and high $B A A L C$ expression are independent prognostic markers in childhood acute myeloid leukemia. Blood. 2011 Nov 24;118(22):5905-13.

9. Najima Y, Ohashi K, Kawamura M, Onozuka Y, Yamaguchi $\mathrm{T}$, Akiyama $\mathrm{H}$, et al. Molecular monitoring of BAALC expression in patients with CD34-positive acute leukemia. Int J Hematol. 2010;91:636-645.

10. Damiani D, Tiribelli M, Franzoni A, Michelutti A, Fabbro D, Cavallin M, Toffoletti E, Simeone E, Fanin R, Damante G. BAALC overexpression retains its negative prognostic role across all cytogenetic risk groups in acute myeloid leukemia patients. Am J Hematol. 2013;88(10):848-852.

11. Pogosova-Agadjanyan E, Moseley A, Othus M, Appelbaum F, Chauncey T, Chen I, Erba H, Godwin J, Fang M, Kopecky K, List A, Pogosov G, Radich J, Willman C, Wood B, Meshinchi S, Stirewalt D. Impact of specimen heterogeneity on biomarkers in repository samples from patients with acute myeloid leukemia: A SWOG report. Biopreserv Biobank. 2018;16(1):42-52.

12. Morita K, Masamoto Y, Kataoka K, Koya J, Kagoya Y, Yashiroda H, Sato T, Murata S, Kurokawa M. BAALC potentiates oncogenic ERK pathway through interactions with MEKK1 and KLF4. Leukemia. 2015;29(11):2248-2456.
13. Costello R, Mallet F, Gaugler B, Sainty D, Arnoulet C, Gastaut J, Olive D. Human acute myeloid leukemia CD34+/ CD38- progenitor cells have decreased sensitivity to chemotherapy and Fas-induced apoptosis? Reduced immunogenicity, and impaired dendritic cell transformation capacities. Cancer Res. 2000;60:4403-4411.

14. Gerber J, Smith B, Ngwang B, Zhang H, Vala M, Morsberger L, Galkin S, Collector M, Perkins B, Levis M, et al. A clinically relevant population of leukemic CD34+CD38cells in acute myeloid leukemia. Blood. 2012;119(15):35713577.

15. Gerber J, Zeidner J, Morse S, Blackford A, Perkins B, Yanagisawa B, Zhang H, Morsberger L, Karp J, Ning Y, Cocke C, Rosner G, Smith D, Jones R. Association of acute myeloid leukemia's most immature phenotype with risk groups and outcomes. Haematologica. 2016;101950;607-615.

16. Jentzsch M, Bill M, Nicolet D, Leiblein S, Schubert K, Pless M, Bergmann U, Wildenberger K, Schuhmann L, Cross M, et al. Prognostic impact of the CD34+/CD38- cell burden in patients with acute myeloid leukemia receiviung allogeneic stem cell transplantation. Am J Hematol. 2017;92(4):388-396.

17. Plesa A, Dumontet C, Mattei E, Tagoug I, Hayette S, Sujobert P, Tigaud I, Pages M, Chelghome Y, Baracco F, et al. High frequqncy of CD34+CD38-/low immature leukemia cells is correlated with unfavorable prognosis in acute leukemia. World J Stem Cells. 2017;9(12):227-234.

18. Thomas D, Majeti R. Biology and relevance of human acute myeloid leukemia stem cells. Blood. 2017;129(12):15771585.

19. Mamaev N, Gudozhnikova Y, Gindina T, Barkhatov I, Shakirova A, Katerina V, Gubina M, Nikolaeva E, Semenova E, Paina O, Darskaya E, Pirogova O, Porunova V, Moiseev I, Mikhailova I, Ayubova B, Kravtsova V, Bondarenko S, Zubarovskaya L, Afanasyev B. Efficacy of Chemotherapy in Acute Leukemia Patients Resistant to Previous Standard Treatment According to the Series Measurement of WT1 Gene Expression. Clinical Oncohematology. 2018;11(1):7888 (In Russian).

20. Minetto P, Guolo F, Clavio M, de Astis E, Colombo N, Grasso R, Fugazza G, Sessarego M, Lemoli R, Gobbi M, Miglino M. Combined assessment of WT1 and BAALC gene expression at diagnosis may improve leukemia-free survival prediction in patients with myelodysplastic syndromes. Leukemia Res. 2015;39:866-873.

21. Haferlach C, Kern W, Schindela S, Kohlmann A, Alpermann T, Schnittger S, Haferlach T. Gene expression of $B A A L C, C D K N 1 B, E R G$, and $M N 1$ adds independent prognostic information to cytogenetics and molecular mutations in adult acute myeloid leukemia. Genes Chromosomes Cancer. 2012;51(3):257-265.

22. Gudozhnikova Y, Mamaev N, Barkhatov I, Katerina V, Gindina T, Shakirova A, Bondarenko S, Slesarchuk O, Darskaya E, Paina O, Zubarovskaya L, Afanasyev B. Results of Molecular Monitoring in Post-transplant Period by Means of Series Investigation of WT1 Gene Expression in Patients with Acute Myeloid Leukemia. Clinical Oncohematology. 2018;11(3):241-251 (In Russian). 
23. Shakirova A, Barkhatov I, Churkina A, Moiseev I, Gindina T, Bondarenko S, Afanasyev B. Prognostic significance of $B A A L C$ overexpression in patients with AML during the post-transplant period. Cell Ther Transplant. 2018;7(2): 54-63.

24. Cilloni D, Renneville A, Hermitte F, Hills R, Daly S, Jovanovic J, Gottardi E, Fava M, Schnittger S, Weiss T, Izzo B, Nomdedeu J, van der Heijden A, van der Reijden B, Jansen J, van der Velden V, Ommen H, Preudhomme C, Saglio G,
Grimwade D. Real-time quantitative polymerase chain reaction detection of minimal residual disease by standardized WT1 assay to enhance risk stratification in acute myeloid leukemia: a European LeukemiaNet study. J Clin Oncol. 2009;27(31):5195-5201.

25. Reinisch A, Thomas D, Corces MR, et al. A humanized bone marrow ossicle xenotransplantation model enables improved engraftment of healthy and leukemic human hematopoietic cells. Nat Med. 2016;22(7):812-821.

\title{
Клиническое значение феномена гиперэкспрессии гена $B A A L C$ при прогнозировании посттранспланта- ционных рецидивов у больных острым миелоид- ным лейкозом
}

\author{
Алена И. Шакирова, Николай Н. Мамаев, Ильдар М. Бархатов, Яна В. Гудожникова, Татьяна Л. Гиндина, \\ Елена В. Бабенко, Борис В. Афанасьев \\ НИИ детской онкологии, гематологии и трансплантации им. Р. М. Горбачевой; кафедра гематологии, трансфузиологии \\ и трансплантологии Первый Санкт-Петербургский государственный медицинский университет им. И. П. Павлова, \\ Санкт-Петербург, Россия
}

\section{Резюме}

Цель изучения состояла в выяснении тесных связей между популяциями костномозговых бластных элементов, повышение содержания которых определяет цитологический рецидив ОМЛ, и ответственных за рецидив лейкозных клеток предшественников. В клиническом плане, мы имели целью оценку потенциала развития рецидивов лейкоза после трансплантации гемопоэтических клеток (ТГСК). Посттрансплантационные рецидивы (ПТР), с точки зрения их биологических механизмов, могут выявляться по гиперэкспрессии определенных генов, связанных с клеточной диффеенцировкой.

\section{Пациенты и методы}

В исследование вошло 61 больных ОМЛ, леченных с помощью алло-ТГСК, у которых осуществлено одновременное серийное измерение уровней экспрессии генов BAALC и WT1 методом количественной ПЦР в реальном времени с использованием ген-специфических праймеров.

\section{Результаты}

В группе из 12 больных с повышенным уровнем экспрессии гена WT1 и с нормализованным до 4 \% содержанием бластных элементов в костном мозге на момент проведения аллогенной трансплантации гемопоэтических стволовых клеток (алло-ТГСК) было показано, что подгруппа с повышенной экспрессией гена BAALC характеризуется: а) более высоким числом ПТР ( $\mathrm{p}=0,002) ;$ а также б) укорочением сроков безрецидивной выживаемости (БРВ) при сопоставлении с группой сравнения $(\mathrm{p}=0,019)$. Дальнейшее использование этого прогностически неблагоприятного критерия, состоящего из одновременного повышения уровней экспрессии обоих генов при анализе основного массива данных, показало его более частое обнаружение у больных с M1, M2, M0, M4 и М5 ФАБ- цитологическими вариантами. При этом предварительные данные указывают на худшую общую выживаемость (228 дней) в группе больных ОМЛ, имевших сочетанную гиперэкспрессию обоих генов как непосредственно перед ТГСК, так и в посттрансплантационном периоде.

\section{Заключение}

Потенциальная клиническая значимость полученных данных, касающихся повышенной экспрессии гена BAALC у взрослых и детей больных ОМЛ, леченных с использованием алло-ТГСК, и особенно, наличия феномена сочетания у них гиперэкспрессии генов BAALC и WT1 несомненна, что диктует необходимость активного использования их в клинике.

\section{Ключевые слова}

Острый миелоидный лейкоз, аллогенная трансплантация гемопоэтических клеток, посттрансплантационные рецидивы, гены BAALC и WT1, одновременная гиперэкспрессия, клиническая значимость, прогноз. 